4. Karas, S. O. (2006). Interpretation of baroque music on bayan (theoretical-performing aspect). Extended abstract of candidate's thesis. Lviv: LSMA named M. V. Lysenko [in Ukrainian].

5. Musical hermeneutics. Retrieved from http://www.etheroneph.com/audiosophia/144 muzykalnaya-germenevtika.html [in Ukrainian].

6. Nosina, V. B. (1993). Symbolics of music by I. S. Bach. International courses of the highest artistic mastery of pianists by memory of S. V. Rakhmaninov. Tambov [in Ukrainian].

7. Organ creation of Bach. Lectures of musical literature musike.ru: Bach. Retrieved from http://musike.ru/index.php?id=10 [in Ukrainian].

8. Teutu, I. P. (2016). Transcription in the ukrainian cymbal art: historical and theoretical aspects. Extended abstract of candidate's thesis. Kyiv: Institute of art, folklore and ethnology named Maxim Rylsky [in Ukrainian].

9. Cherednichenko, T. V. (1990). Music hermeneutics. G. V. Keldysh (Eds.), Music encyclopedic dictionary (p. 465). Moscow: Soviet encyclopedia [in Ukrainian].

10. Cherneta, T. (2009). Implication of authentic kobzar traditions in modern music practice. Art criticism notes: collection sciences works (issue 15), (pp. 5863). Kyiv [in Ukrainian].

11. Schweitzer, A. Johann Sebastian Bach. Moscow: Music [in Ukrainian].

Стаття надійщла до редакції 08.06.2016

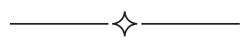

УДК $78.03+78.05 / .07$

Володимир Петрович Клещуков, здобувач кафедри історії музики та музичної етнографії

ОНМА ім. А. В. Нежданової

\title{
ВЗАЕМОДІЯ ХОРЕОГРАФА ТА КОНЦЕРТМЕЙСТЕРА ЯК ОСНОВА ІНТЕРПРЕТАЦІЙНОГО ПРОЦЕСУ
}

Мета роботи. Устатті аналізуються специфічні параметри творчої взаємодії концертмейстера та хореографа в репетиційному та концертно-виконавському процесі на основі спільних когнітивно-виконавських засад. Методологія дослідження полягає в застосуванні загальнонаукових підходів і принципів - системного, синергетичного, історичного, еволюційного підходів, принципу додатковості, а також компаративного, естетико-культурологічного, історичного методів, музикознавчого підходу. Наукова новизна роботи полягає в розширенні уявлень про феноменологічні аспекти спільної музично-хореографічної інтерпретації y мистецтвознавчому та виконавсько-теоретичному аспектах. Bu-

(C) Клещуков В. П., 2016 
сновки. Осмислення спільності творчо-когнітивних, художньо-мовних, психологічних аспектів музично-інструментального та хореографічного мистецтв, виконавської специфіки концертмейстерської майстерності у хореографічному класі дозволяє виявити феноменологічний статус музично-танцювальної єдності як художньої цілісності навіть поза межами власне синтетичних жанрів. Це актуалізує значущість взаємодіі хореографа та концертмейстера у необхідному процесі спільної інтерпретативної діяльності.

Ключові слова: музика, танець, хореографічне мистецтво, інтерпретація когнітивно-виконавські властивості, хореограф, концертмейстер, музична інтонація, пластична інтонація, спільна інтерпретація.

Kleschukov Volodymyr Petrovich, The Odessa National A. V. Nezhdanova Academy of Music, applicant of the department of history of music and musical ethnography

\section{Interaction of choreographer and concertmaster as the basis of interpreta- tion process}

Objective The article analyzes the specific parameters of the creative interaction of the concertmaster and the choreographer in the rehearsal and concert-performing process on the basis of joint cognitive-performing principles. The methodology of the research consists in the application of general scientific approaches and principles - systemic, synergetic, historical, evolutionary approaches, the principle of additionality, as well as comparative, aesthetic-cultural, historical methods, musicology approach. The scientific novelty of the work is to broaden the concepts of the phenomenological aspects of the joint musical-choreographic interpretation in art criticism and performing-theoretical aspects. Conclusions Understanding the commonality of creatively-cognitive, artistic and linguistic, psychological aspects of musical instrumental and choreographic arts, performance specificity of concertmaster's skills in the choreographic class allows to reveal the phenomenological status of musical-choreographic unity as an artistic integrity even beyond the limits of the actual synthetic genres. It actualizes the significance of the interaction of the choreographer and the concertmaster in the necessary process of joint interpretive activity.

Keywords: music, dance, choreographic art, interpretation, cognitive-performance properties, choreographer, concertmaster, musical intonation, plastic intonation, common interpretation.

Клешуков Владимир Петрович, соискатель кафедры истории музыки и музыкальной этнографии ОНМА им. А. В. Неждановой

Взаимодействие хореографа и концертмейстера как основа интерпретационного процесса

Цель работы. В статье анализируются специфические параметры творческого взаимодействия концертмейстера и хореографа в репетиционном и концертно-исполнительском процессе на основе общих когни- 
тивно-исполнительских принципов. Методология исследования заключается в применении общенаучных подходов и принципов - системного, синергетического, исторического, эволюционного подходов, принципа дополнительности, а также сравнительного, эстетико-культурологического, исторического методов, музыковедческого подхода. Научная новизна работы заключается в расширении представлений о феноменологических аспектах совместной музыкально-хореографической интерпретации в искусствоведческом и исполнительно-теоретическом аспектах. Выводы. Осмысление общности творчески когнитивных, художественно-языковых, психологических аспектов музыкально-инструментального и хореографического искусств, исполнительской специфики кониертмейстерского мастерства в хореографическом классе позволяет выявить феноменологический статус музыкально-танцевального единства как художественной целостности даже за пределами собственно синтетических жканров. Это актуализирует значимость взаимодействия хореографа и кониертмейстера в необходимом процессе совместной интерпретативной деятельности.

Ключевые слова: музыка, танеи, хореографическое искусство, интерпретация, когнитивно-исполнительские свойства, хореограф, концертмейстер, музыкальная интонация, пластическая интонация, общая интерпретация.

Актуальність теми дослідження. Танець здавна існував у тісній єдності з музикою (а також з поезією [9]). 3 XVII століття до цього синтезу «приєднується» риторика, яка в цю епоху справила вплив і на музичне мистецтво, зокрема, в його «чистому» форматі. Риторичні принципи вповні виявляють свої «регуляторні» формотворчі і змістовні функції у хореографічному мистецтві - від мініатюри до великих концертних та балетних форм. На цей процес справила свого часу вплив актуалізація античних традицій. Л. Пилаєва вбачає у такому зв’язку музики, танцювального руху і слова свого роду продовження «синкретичної єдності стародавнього мистецтва, побаченого очима творців придворних музично-сценічних постановок у стилі французького класицизму», відтворення «родини» мистецтв як «співтворчості муз» [9].

Але хореографічне і музичне мистецтва все ж мають чи не найбільше коло творчо-когнітивних «спільнот». Це, перш за все, невербальна форма мислення і самовираження (хоча в тій чи іншій мірі обидва завжди потребували під впливом слова або у тісному зв'язку з ним); метро-ритмічна основа як відтворення рухової природи; артикуляційні, гучнісно-динамічні, «дихально»-синтаксичні засади тощо. Відповідно вказані параметри впливають й на виконавський зріз обох 
видів мистецтв. Пози, кроки, міміка, жести, танцювальні рухи танцюристів сприймаються як елементи виразного мовлення і можуть бути асоційованими з музично-інструментальними, перш за все, виконавськими засобами і прийомами. Тож музична мова і образна сторона музики, у своєму «акомпануючому» статусі, загострюють, підкреслюють значимість хореографічних засобів. Останні у комплексі пластики рук, корпусу, нахилів або поворотів голови, різноманітних хореографічних па сприяють танцюристові виказати свої думки і почуття, повідомити присутнім ті чи інші «рухи душі». У ракурсі вказаних когнітивних та мовних «спільнот» особливої уваги набуває робота концертмейстера хореографічного класу, а також його спільне мислення, творча взаємодія з хореографом-керівником і танцюристами.

Метою дослідження є визначення специфічних параметрів професійної діяльності концертмейстера хореографічного класу у його тісній взаємодії з роботою хореографа на основі спільних когнітивно-виконавських засад.

Виклад основного матеріалу. До останніх десятиріч діяльність концертмейстера не поставала предметом спеціальної уваги науковців, хіба що з точки зору їх упорядкування з основним, сольним «матеріалом» - звучанням музичних інструментів, вокалістів тощо. Ще менше такої уваги приділялося концертмейстерам хореографічного спрямування, адже вони, як правило, не приймають участі у сценічних виступах, де частіше застосовують живе ансамблево-оркестрове або записане у фонограмі звучання музики. Концертмейстер же задіяний більше у репетиційному процесі, у форматі хореографічного уроку. Практикуючі хореографи і концертмейстери знають, якої значущості набуває їх співтворчість у ході уроку. 3 іншого боку, останнім часом і сама сучасна культура, і іiї дослідники відчувають зростання уваги до тих форм мистецької діяльності, які тривалий час вважалися другорядними, як то акомпаніатор-концертмейстер у хореографічному мистецтві. Але ж його діяльність належить до важливішої ланки як музично-виконавського мистецтва, педагогіки (музичної та хореографічної), так і хореографічного виконавства у всіх сферах культури.

Відомо, що танець потребує музики, часто викликається нею. Саме музика організовує метро-ритмічний бік хореографічної пластики, спрямовує почуття, передані в танці, а також відповідну манеру хореографічного виконання. Умови та виконавські засади вказаного синтезу можна вбачати вже в синкрезисі грецької хореї, що дещо іншими засобами і на іншому функціональному рівні буде відтворене 
в мистецтві балету насамперед, але своєрідно проявляється і у будьякому хореографічному художньому чи навчальному акті. «Збереження пари «танцювальне - пластичне» і після «розщеплення» єдиного стародавнього мистецтва на ряд самостійних наділяє іiї якостями генетичного коду» $[3,5]$. Т. Арбо - автор трактату «Оркезографія», одного з найстаріших збережених ілюстрованих керівництв, що містить опис танців, популярних в середині XVI століття, музичні приклади і спеціальну табулатуру, розроблену для того, щоб привести танцювальні рухи у відповідність з музикою, - вважав, що музика і $є$ головним витоком виразності танцю. Характерно, що видатні танцюристи XVII-XVIII століть були в той же час і відомими музикантами-виконавцями (Б. Божуайо, Ж. Кордьє, Ж. де Бельвіль та ін.). А найвідоміший видатний композитор, диригент, скрипаль і гітарист Ж.-Б. Люллі був також танцюристом [1, 7]. Анджоліні вказував на необхідність професійного знання музики балетмейстерами, які повинні «... користуватися красотами всіх мистецтв, звертаючись по черзі то до принад танцю, музики, виконавства, а то і до суми всього видовища...» $[1,20]$. Панування в спектаклі технічного, але беззмістовного танцю може допустити лише неук з точки зору музичного боку. Ж.-Ж. Новерр наголошує, що «добра музика повинна живописати, говорити. Відгукуючись на неї, танець стає відлунням, слухняно повторюючи... все, що вона висловлює» $[11,91]$. Пластична природа виразності жестів і танцювальних рухів дозволяє провести аналогії між мистецтвом хореографії і музикою, що опосередковано та прямо виступає підставою, умовою, творчо-виконавською та педагогічною необхідністю взаємодії концертмейстера і хореографа (танцюристів).

У свою чергу відоме висловлення Б. Асафьєва щодо органічної спорідненості музичної і пластичної інтонацій: «Музична інтонація ніколи не пориває зв'язків ні зі словом, ні з танцем, ні з мімікою (пантомімою) тіла людського, але переосмислює закономірності їх форм і складаючих форму елементів у свої музичні засоби виразовості» [2, 4]. Г. Безугла наводить приклади музичних засобів відображення різноманітних властивостей людських рухів. Наприклад, напрямок руху догори/вниз асоціативно-пластично співвідноситься з висхідним/ низхідним музично-мелодійним рухом, амплітудні параметри руху 3 діапазоном мелодії та гучнісно-динамічними характеристиками, різкість руху - стакатною групою штрихів, мелодійні стрибки, динамічні і темброві контрасти, дисонантні утворення, плавність руху групою легатних штрихів, відсутністю стрибків у мелодії і контрастів 
у динаміці, рівномірністю ритмічних структур; інтенсивність руху гучними динамічними засобами, фактурною насиченістю і т. д. [4, 69]. Причому різноманітні виразові компоненти музики доповнюють один одного, сприяючи більш ємному, семантично нашарованому, глибокому сприйняттю як музики, так і хореографічного втілення.

Характерно, що у XX столітті проблема «музичне/пластичне» (у своєрідному з теорією хореографічного мистецтва зустрічному русі) актуалізується в музичній педагогіці. Починаючи від відомого швейцарського педагога Е. Жак-Далькроза склалися різні, у тому числі вітчизняні, методики музично-ритмічного виховання (Д. Кабалевський, Н. Александрова, Н. Збруева, Є. Конорова, М. Румер, В. Яновська, Н. Ветлугіна, К. Тарасова). Однією з найбільш розроблених сучасних методик пластичного інтонування музики є методика «дзеркала» викладача Єрусалимської академії Вероніки Коен (у «дзеркальних» рухах викладача відбивається образно-смислова основа сприймаємої музики, а учні у власному «дзеркалі» повторюють всі рухи вчителя). Сам термін «пластичне інтонування» був введений Т. Вендровою в значенні пластичного еквівалента музичного образу в 1981 році [10]. На відміну від танцю, з власною мовно-семантичною системою, де жест (рух) і музика можуть як доповнювати, так і поліфонічно конфліктувати один з одним для досягнення особливого виразного ефекту, під «пластичним інтонуванням» під музику розуміється втілення через моторику процесу сприйняття музики у всіх iї нюансах (пульсація, сильні долі, ритмічні малюнки, фразування; вільне диригування) [10], що спрямоване на проживання музики в простих і природних рухах рук, голови і корпусу; на формування певних музичних здібностей і сприяння задоволенню природної потреби тіла в руховій реакції на музику. Однак тут не відбувається виявлення музичної тканини в цілісності. Пластичне інтонування було створене як метод активізації сприйняття сенсу музики, як спосіб його усвідомлення, але ще раз свідчить на користь єдності музичної і пластичної інтонацій. Вказують на таку єдність і результати досліджень у галузі музичної психології та нейрофізіології [7].

Звичайно, музика як вид мистецтва створює власний цілісний художній образ, і його неможливо «підмінити» ні словом, ні танцювальним мистецтвом. У випадку синтетичних видів (наприклад, у балеті) художній образ отримує додаткове зорово-пластичне підкріплення. Але і у «чистих» танцювальних жанрах слід особливої уваги надати взаємодії музики і танцю. Музика збагачує зорово-пластичну 
низку художніх вражень, підсилюючи, а часто й скеровуючи сприйняття цілого: «окрім здатності служити тим чи іншим цілям, вона (музика. - B. K.) являє собою особливий світ, володіє власним буттям; вона не розповідає про цей світ, не описує його, але сама є цим світом» $[8,365]$. Пролонгуючи думку Г. Орлова, можна стверджувати, що і танець, слугуючи різним цілям, створює свій художній світ, але в обов'язковому зв'язку з музикою. Тому під час хореографічного виконання концертмейстер так само має враховувати, а значить, і знати тонкощі хореографії (прийоми, термінологію, рисунки, постановку, технологічні моменти тощо).

Так, концертмейстер має оволодіти такою непростою професійною якістю, як розвинута візуально-пластична пам'ять (Г. Безугла називає iї «хореографічною пам'яттю» $[4,142]$ задля свободної орієнтації у двох партитурах - «інструментальній» та «сценічно-хореографічній»). Тож концертмейстеру (і не тільки балетного спектаклю, а й будь-якого окремого танцю) дуже важливо добре знати танцювальну «партію» ${ }^{1}$ виконуваного номера (або танцювальної вправи) - пластично-просторовий рисунок; темпо-метричні аспекти; акцентні «дихальні» моменти; так само, як концертмейстеру вокального, хорового або інструментального класу - мелодійно-інтонаційні, метроритмічні, артикуляційно-тембральні, специфічно-інструментальні (вокальні) властивості твору, інструмента (голосу), конкретного виконавця. Для музиканта-інструменталіста це непросте завдання, пов'язане 3 майже професійним (наразі зорово-пластичним) оволодінням хореографічними виконавськими тонкощами мислення. Починати тут доцільно зі збереження у пам'яті спочатку початкових або ключових елементів хореографічної «партії, основних танцювальних рухів. Але у цій ситуації і хореограф (керівник або виконавець) має не менш добре знати музику (термінологію, логіку дії основних засобів виразовості, жанрово-стильові особливості, історичні аспекти розвитку), що сприятиме не тільки здійсненню шляху «назустріч музикантові» у дрібних виконавських питаннях (наприклад, звідки зараз розпочати), але й яснішому визначенню своєї позиції у відношенні спільної інтерпретації. Відомо, що у практичній роботі навіть існують ноти, якими користувалися досвідчені концертмейстери, з тими чи іншими їх помітками (назвами) рухів, хореографічних прийомів у даних

${ }^{1}$ Термін «партія» тут використовуємо за аналогією до ансамблевого цілого у музиці, підкреслюючи тим самим цілісність хореографічно-музичної взаємодії у мистецтві танцю. 
мотивах, тактах, фразах музики $[4,143]$. Такі «розписані клавіри» можуть з'явитися навіть єдиним матеріальним свідоцтвом достовірності хореографічного тексту, коли постановка (танцю або спектаклю) здійснювалася один раз або інші свідоцтва не збереглися.

Іншою важливою проблемою взаємодії хореографа (танцюриста) і концертмейстера можна вважати «вірний темп», адже обидва види існують у часовій категорії. I ця тема часто може стати «болючою» у спільному інтерпретаційному процесі. Музиканти вимагають від танцюристів здатності чути музику, музикальності виконання, і хореограф не може нехтувати цією властивістю загальної концепції. Але і концертмейстер-музикант має «погодити власні виконавські наміри з хореографічною темповою логікою і ії музичним обгрунтуванням $[4,144]$, власним знанням хореографічного матеріалу, індивідуальними властивостями танцюристів, нарешті, зі спільною музично-хореографічною концепцією твору.

Важливим для концертмейстера хореографічного класу є вміння імпровізувати і грати на слух. Наприклад, за необхідності використання певної частини з цілого музичного твору, з імпровізацією вступу, закінчення, переходів; органічного відносно музики і хореографії завершення музичної фрази у «неквадратній» структурі, поєднання різностильових музичних пластів у синтезі, стилізації віддалених стильових утворень тощо. Одночасно концертмейстер має бачити взаємодію музичних та танцювальних фраз та інших структур, процес візуально-пластичного становлення музичного та хореографічного образів задля втілення їх у єдине сценічне музично-пластичне дійство. В ході формування спільного художнього задуму хореографічного твору важливе діалектичне розуміння: музика часто визначає характер хореографічної постановки, ії тонкощі з можливістю реалізації кількох різних хореографічних рішень, але і хореографічний задум може «задавати тон» у підборі відповідного музичного матеріалу, у тому числі припускаючи використання різних музичних композицій. Провідна роль у цьому процесі, на наш погляд, повинна належати хореографу-постановнику, своєрідності його художнього пластичного мислення за умов знання музики.

Не можна обійти увагою з точки зору взаємодії, окрім вказаних виконавських, ще два аспекти - педагогічний і психологічний. Актуалізація останнього віддзеркалює загальну характеристику психологізації наукового і мистецького дискурсів, життєвих обставин сучасності. У зв'язку з цим особливої ваги набувають питання «про- 
фесійної мобільності», пов'язані з поліфункціональними властивостями як музиканта-концертмейстера, так і хормейстера. Якщо у психології та соціології ця категорія вже достатньо опрацьована, то у сфері мистецтвознавства і музикознавства дослідження ще не проводились. Під професійною мобільністю концертмейстера І. Бутова розуміє «комплексну інтегральну характеристику особистості, яка базується на когнітивно-діяльнісному фундаменті музичних (додамо i хореографічних. - $B$. $K$.) знань, виконавських умінь і навичок, передбачає емоційно-артистичну реактивність, соціально-творчу адаптивність, репетиційно-сценічну поведінкову варіативність і забезпечує ефективне виконання поліфункціональної і багатопрофільної діяльності» [5, 2]. Ї̈̈ структура включає наступні компоненти: когнітивно-діяльнісний; особистісно-психологічний; соціально-комунікативний; рольовий варіативний з готовністю до швидкої зміні виконуваної функції. Усе перелічене має відношення й до інтегральної характеристики хореографа, співпрацюючого з концертмейстером в напрямку створення спільної інтерпретації.

Висновки. Осмислення спільності творчо-когнітивних, художньо-мовних, психологічних аспектів музично-інструментального та хореографічного мистецтв, виконавської специфіки концертмейстерської майстерності у хореографічному класі дозволяє виявити феноменологічний статус музично-танцювальної єдності як художньої цілісності навіть поза межами власне синтетичних жанрів. Це актуалізує значущість взаємодії хореографа та концертмейстера у необхідному процесі спільної інтерпретативної діяльності, в спільній роботі концертмейстера і хореографа органічно поєднуються, варіативно змінюються в залежності від контексту і умов діяльності музичні та хореографічні виконавські, педагогічні, організаційно-психологічні аспекти, що дозволяє розглядати основний предмет дослідження як цілісний і унікальний феномен.

\section{СПИСОК ЛІТЕРАТУРИ}

1. Асафьев Б. Люлли и его дело. De тъsica. Вып. 2. Л., 1926. С. 5-27.

2. Асафьев Б. Музыкальная форма как процесс. Кн. 1, 2. Изд. 2-е. М. - Л.: Музыка, 1971. 376 с.

3. Афанасьева О. В. Творчество личности как социально-духовный феномен: автореф. дис. ... д-ра соц. наук: 22.00 .06 / Рос. Акад. наук. Ин-т соц.полит.исслед. Москва, 1999. 43 с.

4. Безуглая Г. А. Анализ танцевальной и балетной музыки: учеб. пособие. СПб.: Изд-во политехн. Ун-та, 2009. 177 с. 
5. Бутова И. Формирование профессиональной мобильности музыканта-концертмейстера в процессе обучения в музыкальном колледже: автореф. дис. ... канд. пед. наук: 13.00.02 / Ур. гос. пед. ун-т. Екатеринбург, 2011. $24 \mathrm{c}$.

6. Вендрова, Т. «Пластическое интонирование» музыки в методике Вероники Коэн / Т. Вендрова // Искусство в школе. - 1997 - № 1 - С. 61-64; № 2 - С. $64-67$; № 4 - С. $61-64$

7. Гракова В. В. Пластическое интонирование на уроках музыки: теория и практика. URL: http://elib.bspu.by/bitstream/doc/1625/1.pdf

8. Орлов Г. Древо музыки. Вашингтон - СПб.: Сов. композитор,1992. $408 \mathrm{c}$.

9. Пылаева Л. Д. Музыка сценических танцев французских композиторов XVII - начала XVIII веков в контексте риторической эпохи : дис. ... д-ра искусствовед.: 17.00.02 / Российская академия музыки им. Гнесиных. Москва, 2012. $412 \mathrm{c}$.

10. Художественное творчество и ребенок: монография / под ред. Н. А. Ветлугиной. М.: Педагогика, 1972. 287 с.

11. Чебуркина М. К проблеме термина «французское барокко»: «музыка барокко» Ж.-Ж. Руссо (1768). Музыковедение. 2011. № 2. С. 2-9.

\section{REFERENCES}

1. Asafiev, B. (1926). Lully and his case. De mzsica. Leningrad. 5-27 [in Russian].

2. Asafiev, B. (1971). Musical form as a process. Moskva. 376 [in Russian].

3. Afanasyeva, O. V. (1999). Creativity of personality as a socio-spiritual phenomenon. Extended abstract of doctor's thesis. Moscow: Ros. Acad. sciences. Institute of Social and Political Studies. 43 [in Russian].

4. Bezuglaya, G. A. (2009). Analysis of dance and ballet music. SPb.: Publishing house of polytechnic. University, 177 [in Russian].

5. Butova, I. (2011). Formation of professional mobility of the musician-accompanist in the process of training in music college. Extended abstract of doctor's thesis. Ekaterinburg: Ur. state. ped. un-t. 24 [in Russian].

6. Vendrova, T. (1997). «The plastic intonation» of music in the technique of Veronica Cohen. Art at school. 1. 61-64; 2. 64-67; 4. 61-64 [in Russian].

7. Grakova, V. V. Plastic intonation in music lessons: theory and practice. Retrieved from http://elib.bspu.by/bitstream/doc/1625/1.pdf [in Russian].

8. Orlov, G. (1992). The tree of music. Washington - St. Petersburg: Sov. composer,. 408 [in Russian].

9. Pylaeva, L. D. (2012). Music of scenic dances of French composers of the 17 th - early 18th centuries in the context of the rhetorical era. Doctor's thesis. Moscow: Russian Academy of Music. Gnessins [in Russian].

10. Vetlugina, N. A. (Eds.). (1972). Artistic creativity and child. monograph. M.: Pedagogy. 287 [in Russian]. 